\title{
Solar protection influence on dynamic insulation efficiency of double skin façades
}

\author{
Nelu-Cristian Cherecheș ${ }^{1}$, Cătălin George Popovici ${ }^{1}$, Vasile Valerică Cîrlan ${ }^{1}$, and Sebastian Valeriu Hudișteanu ${ }^{1, *}$ \\ 1“Gheorghe Asachi” Technical University of Iaşi, Faculty of Civil Engineering and Building Services, Romania
}

\begin{abstract}
The objective of the study was to perform a numerical analysis in order to determine the best position for placing sunscreen inside the channel of a double skin façade insulation relative to dynamic insulation efficiency, using ANSYS-Fluent software. The analysis was performed for summer conditions in forced convection for two airspeed regimes inside the channel: $0.2 \mathrm{~m} / \mathrm{s}$ and respectively $0.5 \mathrm{~m} / \mathrm{s}$. Regime is considered permanent and the only parameter changed is the position of the blinds in the channel. Results are shown by spectra and profiles of temperature and velocity in order to analyse thermodynamic behaviour of a double skin façade. The numerical results emphasize that effectiveness of sunscreen such as blinds, is proportional to the flow velocity inside the channel and inversely proportional to the distance from the outer glazing. Ranked as the most effective sun protection is when it is located at the outer glazing and air velocity at the entrance is $0.5 \mathrm{~m} / \mathrm{s}$.
\end{abstract}

\section{Introduction}

Double skin façade coating (DSF) represents a modern solution for thermal protection of buildings. The façade consists in two layers of glazing, one towards the outside and the other towards the protected area of the building. The space between the two glass panels is often called "channel façade" [1].

The study conducted by Amir Hossein [2] recommends the intelligent façade for the further development of buildings with low energy consumption. Channel thickness varies from 5 centimetres to 2 meters L. Xu et al. [3] analysed channel thicknesses ranged from 0.5 meters to 1 meter. To enhance the effectiveness of the façade in summer, the channel is often vented. Ventilation must ensure reducing overheating in summer, and also reducing energy consumption in winter [4]. Another important component of this type of façade is sunscreen and protection types most commonly used are venetian blinds. In this way the level of natural light inside the building is also controlled. Relevant literature $[5-7,22]$ reveals studies on thermal behaviour and the flow of air through the double glass façade equipped with solar protection. These studies have focused on analysing the impact of sunscreen on temperature fields, depending on the position of the blinds and the angle of sun protection.

In the studies [8,9], authors have analysed the behaviour of double skin façade for various configurations. These configurations must necessarily relate to external climatic conditions and those inside the building and a poor operation of the façade could lead to inappropriate results.
Numerical simulations on DSF [10-12] have shown that with the increasing channel thickness, thermal resistance of the façade also increases. This is due to the reduction of convective heat transfer coefficients of the bounding surfaces.

Heating and cooling air inside the channel in comparison with the inner glazed façade is analysed by [13]. Analysis shows heating and cooling loads as well as intermediate surface temperature estimation during three months (January, April, and July) for west-facing ordinary glass façade and high absorption glass. This configuration has lower heat loss in winter, in January, when the channel is closed, while in July this configuration has the smallest façade heat gains. Analysis of the glazing and the ventilation mode given by [13] was performed on 90 combinations of double skin façade glazing. The best results were obtained for triple glazing configuration inside the double skin façade.

The most important element of DSF is glass, and different glass properties are studied in [14]. Climatic conditions for the location of the building are very important in choosing the right type of glass.

Analysis of the cold climate façade was performed by [15] and the number of glass panels resulted in energy performance compared with double and triple glazing, of $22 \%$ and $24 \%$. For four and five glass panels' energetic performance was higher, about $40 \%$ or $60 \%$, due to external light and natural solar factor provided by the number of panels.

Increased energy consumption for buildings in Hong Kong, has led to the need to implement and study the behaviour of double skin façade. Studies were performed on calculating the value of heat transfer rate for

\footnotetext{
* Corresponding author: sebastian.hudisteanu@tuiasi.ro
} 
commercial buildings by $[16,23]$. The purpose of this study is to obtain a set of correction factors for the calculation of heat transfer rate for commercial buildings with air conditioning, double skin façade and naturally ventilated. For another study, also in Hong Kong [17] showed that photovoltaic panels placed in ventilated double façade glazing offers the lowest solar heat gain coefficient, while for non-ventilated ones, photovoltaic panels have a better coefficient and cuts heat loss.

Another channel ventilated façade system is presented in [18], which describes a new façade insulation for new buildings and renovated based on sandwich panels with ventilated channels. Calculations show that the configuration examined of the ventilated channel is able to provide a low humidity moisture content and good insulating properties of the walls.

The main objective of this study was to determine the sunscreen optimal position inside the channel façade. This analysis was conducted in relation to dynamic isolation efficiency $\varepsilon$ [19] of the system at different flow rates.

\section{Model Description}

Main characteristics of the model are (Fig. 1):

dimensions $-2.1 \mathrm{~m}$ height, $1.5 \mathrm{~m}$ length and $0.3 \mathrm{~m}$ channel width;

façade channel consisting of one exterior simple glass (2) of $6 \mathrm{~mm}$ thickness and one interior doubleglazed type window (3) with $27 \mathrm{~mm}$ thickness, made of 2 layers of glass of $6 \mathrm{~mm}$ respectively $5 \mathrm{~mm}$ thickness and $16 \mathrm{~mm}$ air interspace;

venetian type blinds (8) - made of horizontal metallic adjustable blades of $25 \mathrm{~mm}$ width and $22.5 \mathrm{~mm}$ interspaces; positioned at 1/4 D behind exterior glazing;

air flow balancing grilles, with $50 \%$ obscuration rate, mounted along the façade channel at both supply and exhaust in/out of the channel (6 and 7).

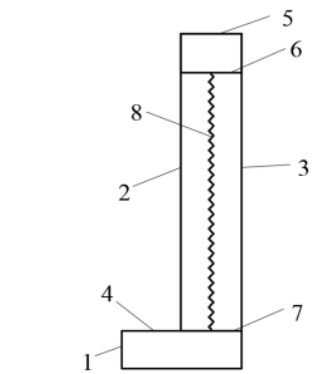

a)

c)

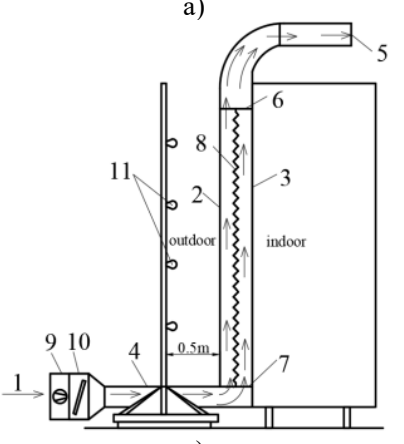

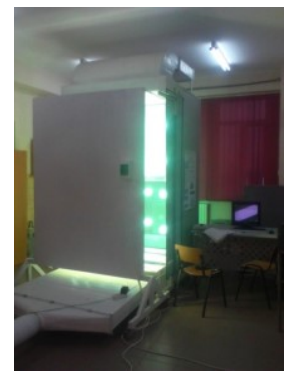

b)

Legend

1 - supply;

2 - exterior glazing

3 - interior glazing;

4 - ducts stand;

5 - exhaust

6 - superior grille;

7 - inferior grille;

8 - blinds;

9 - air ventilator;

10 - valve;

11 - solar lamps.
Fig. 1. Main characteristics of the model.
Thermo-physical properties of the façade component are shown in Table 1.

Table 1. Thermo-physical properties.

\begin{tabular}{|c|c|c|c|c|c|c|c|}
\hline \multicolumn{2}{|c|}{$\begin{array}{l}\text { Component } \\
\text { element }\end{array}$} & $\rho$ & $c_{p}$ & $\lambda$ & $a$ & $\tau$ & $r$ \\
\hline \multicolumn{2}{|c|}{$\begin{array}{l}\text { exterior } \\
\text { glazing }\end{array}$} & 2500 & 670 & 5.3 & 0.11 & 0.82 & 0.07 \\
\hline \multicolumn{2}{|l|}{ air } & 1.225 & 1006 & 0.0242 & 0 & 1 & 0 \\
\hline racks & steel & 8030 & 502.48 & 43 & 0.65 & $0^{*}$ & 0.35 \\
\hline blind & alum & 2719 & 871 & 202.4 & 0.76 & $0^{*}$ & 0.24 \\
\hline \multicolumn{2}{|c|}{$\begin{array}{l}\text { interior } \\
\text { glazing }\end{array}$} & 2500 & 670 & 1.4 & 0.18 & 0.69 & 0.13 \\
\hline
\end{tabular}

*during simulation, solar protection has been considered as semi-

transparent surface with refractive coefficient assimilated with the

corresponding percentage of free surface resulted for the blades

opening angle.

where:

$\rho-$ Density $\left[\mathrm{kg} / \mathrm{m}^{3}\right]$

$c_{p}$ - Specific heat $[\mathrm{J} / \mathrm{kg} . \mathrm{K}]$

$\lambda$ - Thermal conductivity $[\mathrm{W} / \mathrm{m} . \mathrm{K}]$

$a$ - Absorption index

$\tau$ - Refraction index

$r$ - Reflection index

\section{Numerical Hypothesis}

Air system thermal behaviour simulation was performed considering the following climatic parameters:

- direct solar radiation intensity, normal at the surface of the façade, with a constant value of $285 \mathrm{~W} / \mathrm{m}^{2}$;

- diffuse solar radiation intensity: $82 \mathrm{~W} / \mathrm{m}^{2}$;

- exterior air temperature: $30^{\circ} \mathrm{C}$;

- protected surface temperature: $25^{\circ} \mathrm{C}$ - constant.

Ventilation is achieved by forced convection channel with equivalent flow speed in input section of $0.2 \mathrm{~m} / \mathrm{s}$ respectively $0.5 \mathrm{~m} / \mathrm{s}$.

Placement distance of the sunscreen related to exterior glass was: 1/4D; 2/4D and 3/4D.

Results were represented as velocity and temperature spectra in the middle section of the channel at $\mathrm{H}=$ $0.10 \mathrm{~m} ; \mathrm{H}=1.05 \mathrm{~m} ; \mathrm{H}=2 \mathrm{~m}(10 \mathrm{~cm}$ upstream and downstream, respectively input and output section and in the middle of the facade).

Accordingly, there was adopted k-epsilon turbulence model realizable. This model is specific for turbulent air movement because it corresponds with the predominant pressure and recirculation of air currents gradients configurations. Compared with k-epsilon model standard, this model contains alternative formula for the turbulent viscosity and modifies the transport equation for the dissipation rate $\varepsilon$. Studies have shown that this model was validated for configurations where pressure gradients and recirculation are prevalent [20].

The effect of solar radiation was simulated using (DO) model discrete coordinates that solves the radiation transfer equation for a finite number of discrete solid angles. This model is the only pattern that can specify direct and diffuse solar radiation, and is recommended 
for tight spaces. DO is also the only pattern that allows calculation of the non-grey radiation using an approximation wavelength band for the radiation spectrum. Diffusion fraction $\left(d_{f}\right)$ can be specified for each surface and can ascertain the amount of radiation reflected and transmitted by diffusion. For semitransparent materials it is possible to specify an incident input radiation beam.

Solar protection was regarded as semi-transparent surface with incident radiation reduction factor of 0.75 corresponding to a $45^{\circ}$ angle to inclination of the slats of the blind.

Numerical analysis was performed using AnsysFluent simulation program based on the control volume method using a SIMPLE algorithm.

An irregular structural mesh was chosen with small cells near the wall and solar protections with bigger cells inside airflow (Fig. 2). The calculation is an iterative one, convergence criteria chosen are $10^{-6}$ for temperature and $10^{-4}$ both for pressure and speed. An investigation on the input speed of the fluid was performed to study its influence on the heat flow and fluid transfer [21].

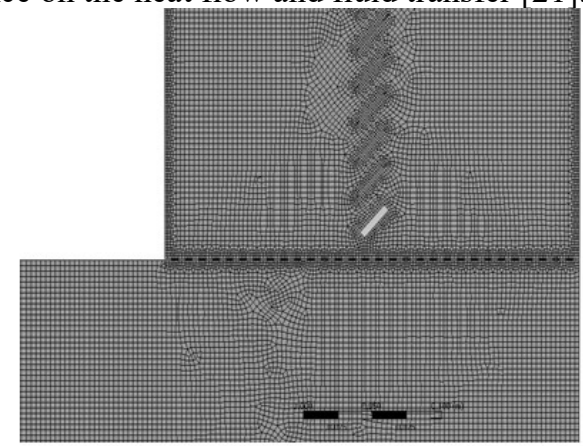

Fig. 2. Mesh of the model.

\section{Modelling results}

Place Solar protection divides the channel façade into two parallel channels of various thickness and thermoaeraulic regimes depending on its position.

Results obtained are shown in the temperature spectra (Fig. 3 and Fig. 4) and respectively speed (Fig. 5 and Fig. 6).

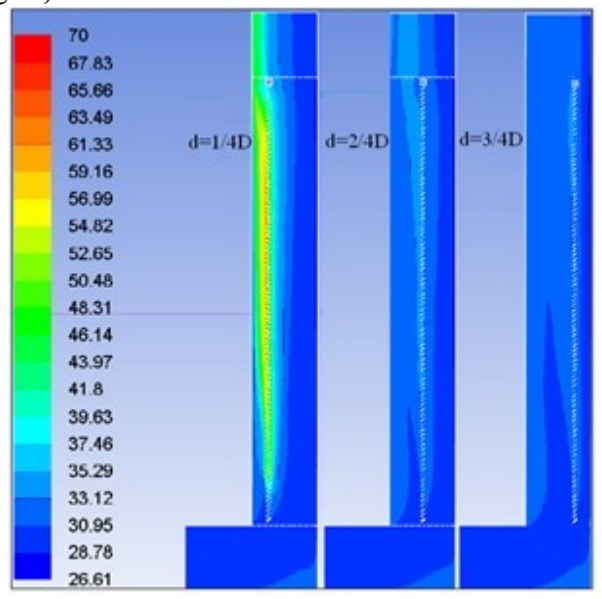

Fig. 3. Spectrum of temperature corresponding to inlet velocity of air of $0.2 \mathrm{~m} / \mathrm{s}$.
One can notice in Fig. 2 or Fig. 3 that the maximum temperatures are reached in the solar protection area, with values ranging between $70^{\circ} \mathrm{C}$ and $65^{\circ} \mathrm{C}$, where the protection is placed to the exterior glazing. Blinds prevent heating the space between them and the inner glazing. The blades temperature is dropping when protection is shifted towards interior glazing, reaching $41{ }^{\circ} \mathrm{C}$ for in the median area and remains approximately constant at around $40^{\circ} \mathrm{C}$, when it is shifted towards the interior glazing. External channel air temperature starts growing through the median area of the façade, when placing the blind in 2/4D position, while positioning the blinds towards the interior glazing, outdoor air temperature channel of the façade is high, especially in the exhaust section.

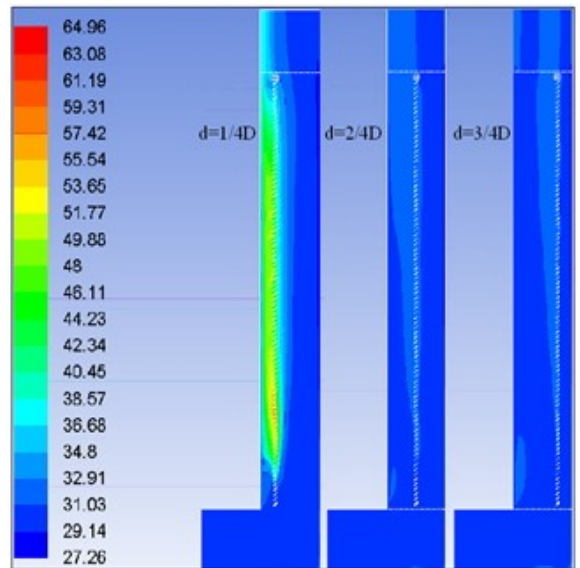

Fig. 4. Spectra of temperature for inlet velocity of $0.5 \mathrm{~m} / \mathrm{s}$.

Also, it is noted that once the air flow is increased or the input speed increases from $0.2 \mathrm{~m} / \mathrm{s}$ to $0.5 \mathrm{~m} / \mathrm{s}$, the temperature of the outside of the façade channel is decreased by about $2^{\circ} \mathrm{C}$ when sunscreen is located near the middle of the channel or interior glazing. For location of the solar protection near the outside glazing, temperatures can reach values higher to $5^{\circ} \mathrm{C}$.

For all three positions of placing the protection velocities are higher in the inner channel, Fig. 4 with values reaching $0.581 \mathrm{~m} / \mathrm{s}$ when the blinds are positioned near the inner glazing.

Maximum speed is reached as soon as the air passes the lower grille. In this way, the air velocity growth in the inner channel causes a lower temperature in this area.

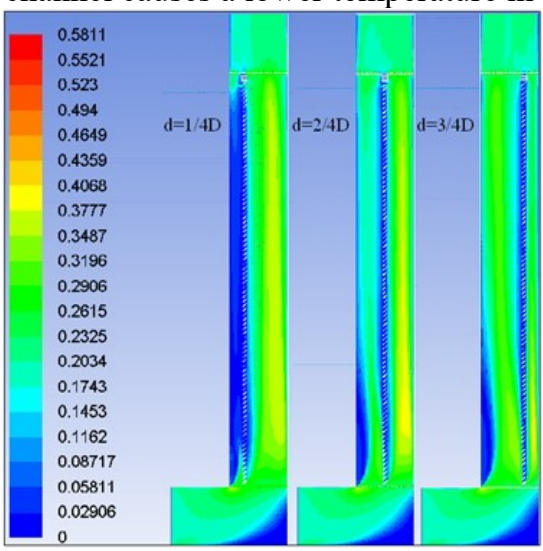

Fig. 5. Spectra of velocities for the three positions of solar protections inside the channels for inlet velocity of $0.2 \mathrm{~m} / \mathrm{s}$. 


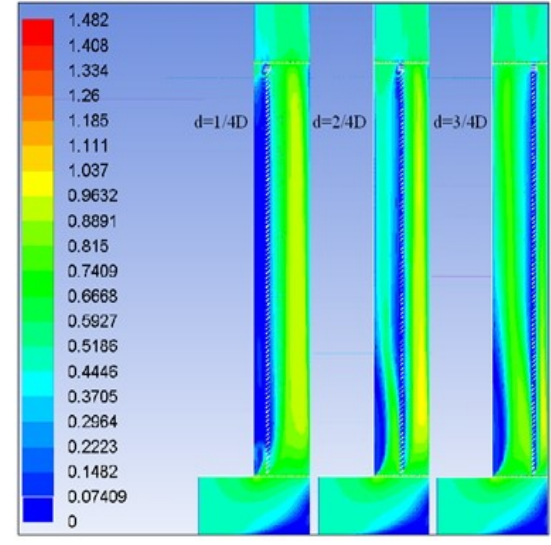

Fig. 6. Spectra of velocities for the three positions of solar protections inside the channels for inlet velocity of $0.5 \mathrm{~m} / \mathrm{s}$.

For this purpose, the values for the parameters studied were represented in three stationary regime control sections in the input, median and output of the façade channel.

The parameter values were determined for each regimen examined, on bounding surfaces inside channels with a step of $\mathrm{D} / 12(2.5 \mathrm{~cm})$.

From the analysis of diagrams, it is noticeable the increase in air temperature along the façade, in particular in the outer channel. In cross section, the temperatures are rising from exterior glazing towards solar protection, and it can be seen a reduction in temperature after the protection towards interior glazing.

This phenomenon is caused by the evolution of the airflow speed in the two channels, which are lower in the outer channel of the façade. Temperatures are dropping on sunscreen when blinds are placed towards interior glazing, ranging from $35 \ldots 37^{\circ} \mathrm{C}$ to $31 \ldots 32^{\circ} \mathrm{C}$. For all cases studied, interior glazing surface temperature is between 27 to $30^{\circ} \mathrm{C}$.

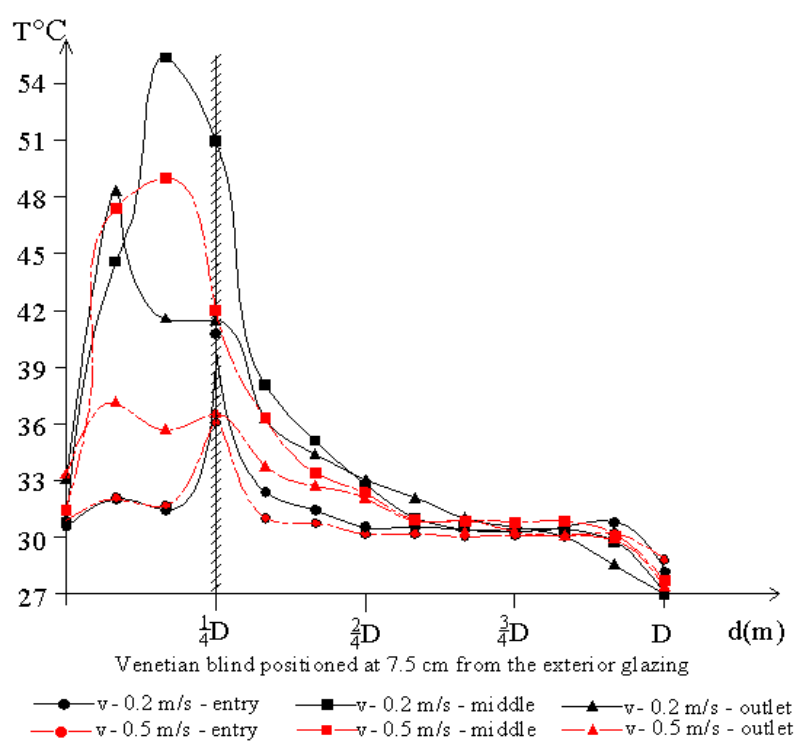

Fig. 7.a. Temperature variation curves for different position of solar protection: $1 / 4 \mathrm{D}$.

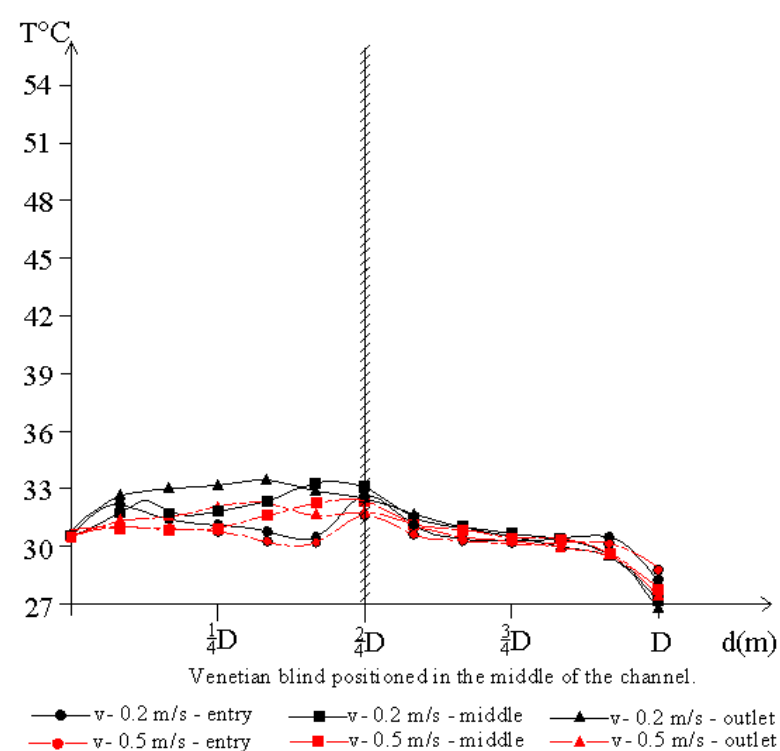

Fig. 7.b. Temperature variation curves for different position of solar protection: $2 / 4 \mathrm{D}$.

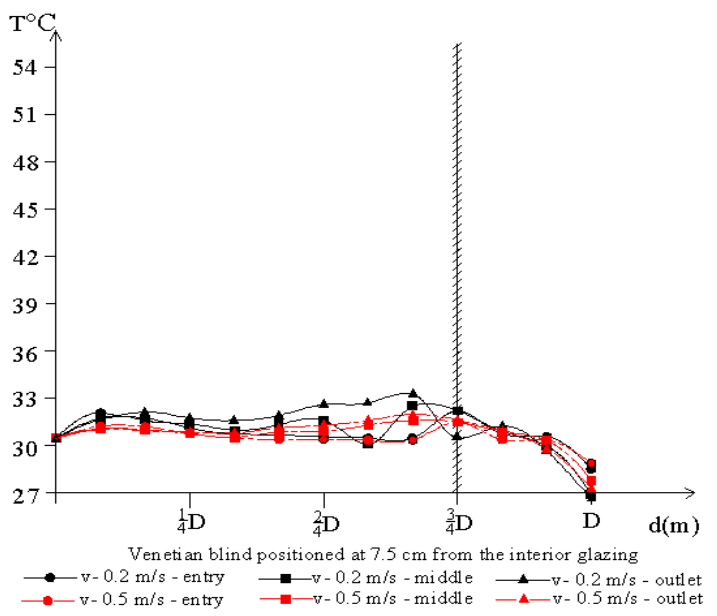

Fig. 7.c. Temperature variation curves for different position of solar protection: 3/4D.

This result is influenced by the fact that part of the incident energy is accumulated in the mass of metal protection, as well as by the reduced solar radiation flow due to the orientation of the blind.

The highest air temperature values are recorded in the middle section and exhaust air channel, for $0.2 \mathrm{~m} / \mathrm{s}$ and for $0.5 \mathrm{~m} / \mathrm{s}$ (Fig. 7a). For a placement of the protection at $7.5 \mathrm{~cm}$ distance against interior glazing, temperatures become similar in all control sections for both inlet velocities. The exterior glazing temperatures are between $31^{\circ} \mathrm{C}$ and $34^{\circ} \mathrm{C}$, while on the inner one they vary between $27^{\circ} \mathrm{C}$ and $30^{\circ} \mathrm{C}$.

Whether sunscreen is positioned in the middle of the channel (Fig. 7b), the temperature inside inlet and outlet sections have the same values for both the input speed of $0.2 \mathrm{~m} / \mathrm{s}$ and to $0.5 \mathrm{~m} / \mathrm{s}$. In addition, in Fig. $7 \mathrm{~b}$ one can observed that the temperature of the exterior glazing is almost identical in all control sections without depending on inlet airflow. Interior glazing temperature varies in the same way as if the protection is placed towards exterior glazing. 
When the sun protections are placed towards interior glazing (Fig. 7c), maximum temperature reaches $32.5^{\circ} \mathrm{C}$ up to $18^{\circ} \mathrm{C}$ lower than if the protection was placed towards exterior glazing. Protection surface temperature difference, when it is placed in the middle of the channel and to the outer glazing, is of only $0.5^{\circ} \mathrm{C}$. Exterior glazing temperature is around $30.5^{\circ} \mathrm{C}$ for all sections studied, and for both speeds inlet. Interior glazing temperature varies between $26.5^{\circ} \mathrm{C}$ and $29^{\circ} \mathrm{C}$.

Highest speeds are achieved in the middle section of the façade, inside inner channel, for inlet velocity rate of $0.2 \mathrm{~m} / \mathrm{s}$ and for $0.5 \mathrm{~m} / \mathrm{s}$ (Fig. 6 to Fig. 8). Average rates in outer channel of the façade are 10 times less than the rates achieved in the inner channel. Maximum speeds are reached near the inner glazing. For areas where sunscreens are located, speeds do not exceed values above $0.05 \mathrm{~m} / \mathrm{s}$.

The evolution of phenomena throughout the height and width of the channel is suggestively represented in the temperature variation (Fig. 7) and the speed variation diagrams (Fig. 8).

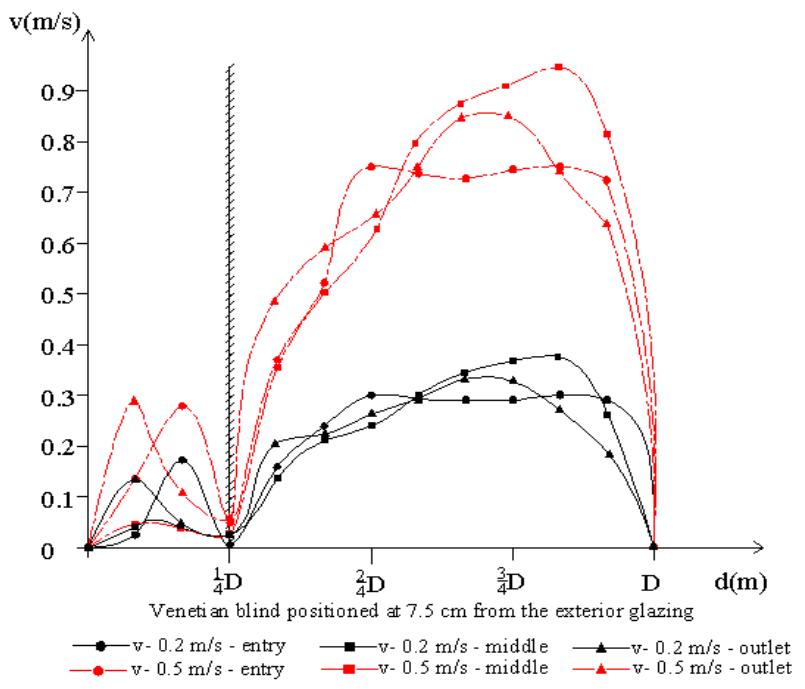

Fig. 8.a. Velocity variation curves for different position of solar protection $1 / 4 \mathrm{D}$.

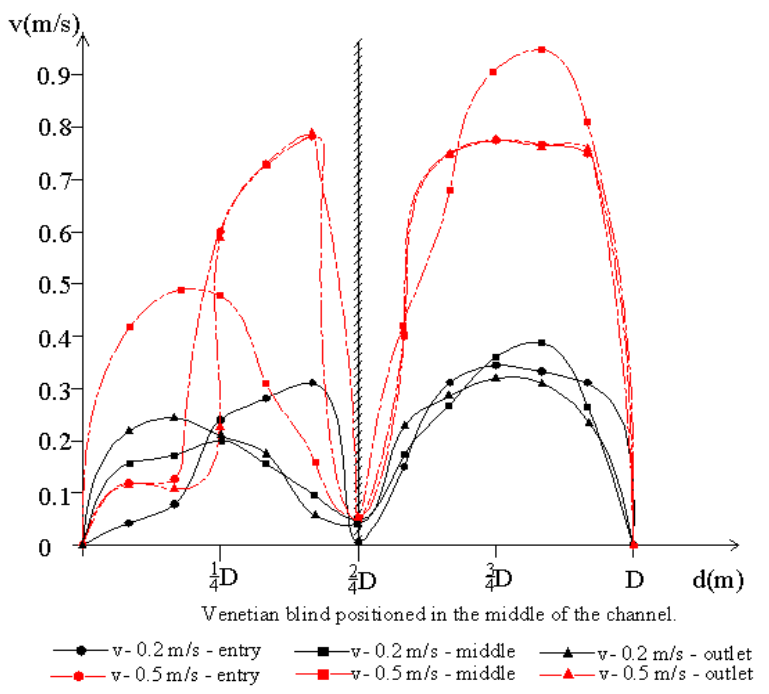

Fig. 8.b. Velocity variation curves for different position of solar protection $2 / 4 \mathrm{D}$.
Average speed of the façade outer channel is about $0.134 \mathrm{~m} / \mathrm{s}$, while inside inner channel is almost double, of $0.248 \mathrm{~m} / \mathrm{s}$ when the air is introduced at a speed of $0.2 \mathrm{~m} / \mathrm{s}$. When the input speed is $0.5 \mathrm{~m} / \mathrm{s}$, the average velocity is about $0.318 \mathrm{~m} / \mathrm{s}$ to the outer channel and $0.647 \mathrm{~m} / \mathrm{s}$ to the inner one (Fig. $8 \mathrm{~b}$ ). The speed value is recorded in the inner channel of the façade, with the value of $0.95 \mathrm{~m} / \mathrm{s}$ for inlet velocity of $0.5 \mathrm{~m} / \mathrm{s}$. Therefore, speeds are approximately equal for the two façade channels, both at the inlet air flow rate corresponding to $0.2 \mathrm{~m} / \mathrm{s}$, as well as for the one corresponding to an air flow rate of $0.5 \mathrm{~m} / \mathrm{s}$ (Fig. $8 \mathrm{c}$ ). These values do not exceed $0.8 \mathrm{~m} / \mathrm{s}$.

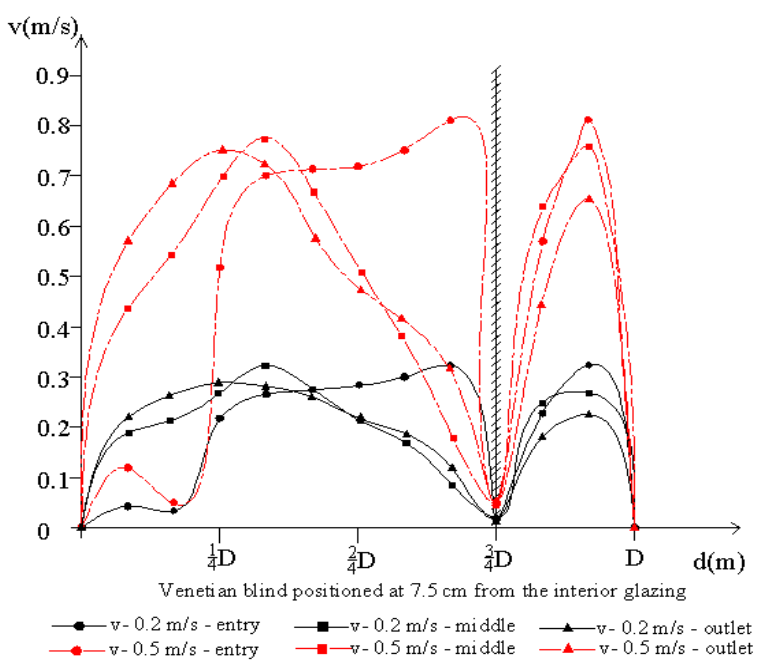

Fig. 8.c. Velocity variation curves for different position of solar protection $3 / 4 \mathrm{D}$.

In all positions of the protection, speeds between blades do not exceed the value of $0.05 \mathrm{~m} / \mathrm{s}$.

Sun protection was considered a semi-transparent surface and the refractive index is equated to the corresponding free surface percentage for an angle of $45^{\circ}$ blinds opening.

For each position of the blind studied, dimensionless criteria values $\mathrm{Re}, \mathrm{Nu}$ were calculated, and convective transfer coefficients $(\alpha)$ to the bounding elements surfaces respectively $\alpha_{c}$ (convective + radiative) inside façade channels (Table 2).

Table 2 presents the convective transfer coefficient values calculated according to the flow regime and the position of venetian blind for the two channels of the façade.

Table 2. Thermo-physical properties.

\begin{tabular}{|c|c|c|c|c|c|c|c|}
\hline Config & Position & $\begin{array}{c}V_{\text {med }} \\
{[\mathrm{m} / \mathrm{s}]}\end{array}$ & $\begin{array}{c}T_{\text {med }} \\
{\left[{ }^{\circ} \mathrm{C}\right]}\end{array}$ & $\operatorname{Re}$ & $\mathrm{Nu}$ & $\begin{array}{c}\alpha_{v} \\
{[\mathrm{~W} / \mathrm{m}} \\
\left.{ }^{2} \mathrm{~K}\right]\end{array}$ & $\begin{array}{c}\alpha_{c} \\
{[\mathrm{~W} / \mathrm{m}} \\
\left.{ }^{2} \mathrm{~K}\right]\end{array}$ \\
\hline \multirow{3}{*}{$\begin{array}{c}\text { Ext. } \\
\text { ch. } \\
\mathrm{V}=0 . \\
2 \mathrm{~m} / \mathrm{s}\end{array}$} & $(1 / 4) \mathrm{D}$ & 0.023 & 45.7 & 166.38 & 1.42 & 12 & 0.242 \\
\hline & $(2 / 4) \mathrm{D}$ & 0.134 & 32.1 & 1846.40 & 10.35 & 12 & 0.927 \\
\hline & $(3 / 4) \mathrm{D}$ & 0.194 & 31.6 & 3845.60 & 18.65 & 12 & 1.156 \\
\hline \multirow{3}{*}{\begin{tabular}{|l} 
Int. \\
ch. \\
$\mathrm{V}=0$. \\
$2 \mathrm{~m} / \mathrm{s}$ \\
\end{tabular}} & $(1 / 4) \mathrm{D}$ & 0.251 & 34.1 & 4975.49 & 10.13 & 8 & 0.628 \\
\hline & $(2 / 4) \mathrm{D}$ & 0.248 & 31.1 & 3417.22 & 17.03 & 8 & 1.525 \\
\hline & $(3 / 4) \mathrm{D}$ & 0.189 & 30.9 & 1367.23 & 8.24 & 8 & 1.400 \\
\hline \multirow{3}{*}{ 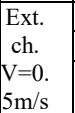 } & $(1 / 4) \mathrm{D}$ & 0.029 & 42.3 & 209.78 & 1.73 & 12 & 0.294 \\
\hline & $(2 / 4) \mathrm{D}$ & 0.318 & 31.6 & 4381.76 & 20.72 & 12 & 1.856 \\
\hline & $(3 / 4) \mathrm{D}$ & 0.471 & 31.1 & 9336.48 & 38.02 & 12 & 2.357 \\
\hline
\end{tabular}




\begin{tabular}{|c|c|c|c|c|c|c|c|}
\hline \multirow{3}{*}{$\begin{array}{l}\begin{array}{l}\text { Int. } \\
\text { ch. } \\
\mathrm{V}=0 . \\
5 \mathrm{~m} / \mathrm{s}\end{array} \\
\end{array}$} & $(1 / 4) \mathrm{D}$ & 0.657 & 33.1 & 13023.5 & 49.28 & 8 & 3.055 \\
\hline & $(2 / 4) \mathrm{D}$ & 0.647 & 31.2 & 8915.09 & 36.65 & 8 & 3.283 \\
\hline & $(3 / 4) \mathrm{D}$ & 0.518 & 30.7 & 3747.23 & 18.41 & 8 & 3.129 \\
\hline
\end{tabular}

Convective transfer index varies between 0.242 and $1.156\left(\mathrm{~W} / \mathrm{m}^{2} \mathrm{~K}\right)$ for exterior channel and inlet speed of $0.2 \mathrm{~m} / \mathrm{s}$, and when inlet speed increases to $0.5 \mathrm{~m} / \mathrm{s}$ indexes values double for protection placements at $2 / 4 \mathrm{D}$ and $3 / 4 \mathrm{D}$. Highest value of the convective exchange coefficient for the inner channel is recorded when protection is located in the middle of the channel, reaching the value of $3.28\left(\mathrm{~W} / \mathrm{m}^{2} \mathrm{~K}\right)$, while for other positions, the convective heat exchange coefficient has a close value, ranging between $3.05\left(\mathrm{~W} / \mathrm{m}^{2} \mathrm{~K}\right)$ and $3.12\left(\mathrm{~W} / \mathrm{m}^{2} \mathrm{~K}\right)$.

\section{Dynamic insulation efficiency}

For comparative and quantifies assessment of energetic effect of the blinds over thermal regime inside DFC susceptible to overheat during summer regime, dynamic insulation efficiency has been calculated, for each blade opening angle. Dynamic insulation efficiency is defined as ratio between heat flow of exhausted air and $\left(Q_{r}\right)$ and total heat flow supplied inside the protected area $\left(Q_{i n c}\right)$.

$$
\varepsilon=\frac{Q_{r}}{Q_{i n c}}
$$

Due to variable thermal regime, induced in the two compartments of façade by solar protection presence, total flow exhausted, $Q_{r}$, has been determined as sum of partial flows.

$$
\begin{aligned}
& Q_{r c 1}=m_{v c 1} \times c_{p} \times \Delta t_{c 1} \\
& Q_{r c 2}=m_{v c 2} \times c_{p} \times \Delta t_{c 2}
\end{aligned}
$$

where:

$m_{v c 1}$ - mass exhausted airflow from the exterior channel; $m_{v c 2}$ - mass air flow exhausted from inside interior channel;

$c_{p}$ - air specific heat;

$\Delta t_{c l^{-}}$- difference between air temperatures at supply and exhaust from the exterior channel of the façade;

$\Delta t_{c 2}$ - difference between air temperatures at supply and exhaust from the interior channel of the façade.

Thermal flow received from the external environment supplied in the protected area, by radiation and convection, in double skin façade respectively is determined by the following equation:

$$
Q_{\text {inc }}=\Pi \tau_{i} \times A \times I+k_{g l o} \times\left(t_{\text {ext }}-t_{\text {int }}\right)+Q_{r c 1}+Q_{r c 2}
$$

where:

$\Pi_{\tau i}$ - intermediate surfaces transmittance product;

$k_{g l o}$ - global heat transfer coefficient;

$t_{\text {int }}$ - inside air temperature, in the protected space;

$t_{\text {ext }}$ - outside air temperature;

I - global solar radiation component, normal along façade surface;
$A$ - façade surface.

$$
k_{g l o}=\frac{1}{\Sigma R_{i}}=\frac{1}{\frac{1}{\alpha_{\text {ext }}}+\frac{1}{\alpha_{\mathrm{int}}}+\Sigma \frac{\delta_{i}}{\lambda}}
$$

where: $R_{i}$ represent the thermal conductive, convective and radiative transfer trough façade elements.

Table 3 presents consecutive values of solar protection calculated accordingly relation no. (1), accordingly with position of solar protection in channel of double skin façade.

Mass air flow determined inside the façade channels $\left(m_{v c l}\right.$ and $m_{v c 2}$ ) was studied according with average velocities for the chosen modelling hypothesis.

\begin{tabular}{|c|c|c|c|c|c|c|c|c|}
\hline $\begin{array}{l}\text { No. } \\
\text { crt. }\end{array}$ & & Config. & $\begin{array}{c}\Pi \tau_{i} \cdot A \cdot I \\
{[W]}\end{array}$ & $\begin{array}{c}k_{g l o} \\
{[\mathrm{~W}]}\end{array}$ & $\begin{array}{c}m_{v c 1} \\
{[\mathrm{~kg} / \mathrm{s}]}\end{array}$ & $\begin{array}{c}m_{v c 2} \\
{[\mathrm{~kg} / \mathrm{s}]}\end{array}$ & $\begin{array}{c}\Delta t_{c 1} \\
{[\mathbf{K}]}\end{array}$ & $\begin{array}{l}\Delta t_{c 2} \\
{[\mathrm{~K}]}\end{array}$ \\
\hline \multirow{3}{*}{1} & \multirow{3}{*}{$\begin{array}{l}\mathrm{v}=0 . \\
2 \mathrm{~m} / \mathrm{s}\end{array}$} & $(1 / 4) \mathrm{D}$ & 60.47 & 0.072 & 0.0031 & 0.1037 & 10 & 1.9 \\
\hline & & $(2 / 4) D$ & 90.07 & 0.076 & \begin{tabular}{|l|}
0.037 \\
\end{tabular} & 0.0683 & 2 & 0.9 \\
\hline & & $s \quad(3 / 4) D$ & 100.36 & 0.076 & 0.0802 & 0.0260 & 1.6 & 0.4 \\
\hline \multirow{3}{*}{2} & \multirow{3}{*}{$\begin{array}{l}\mathrm{v}=0 . \\
5 \mathrm{~m} / \mathrm{s}\end{array}$} & $(1 / 4) \mathrm{D}$ & 60.47 & 0.076 & 0.0039 & 0.271 & 5.9 & 1.2 \\
\hline & & $(2 / 4) D$ & 90.07 & 0.077 & 0.0876 & 0.178 & 1.6 & 0.5 \\
\hline & & 5 & 100.36 & 0.077 & 0.1947 & 0.0713 & 1.1 & 0.3 \\
\hline
\end{tabular}

Incident solar radiation values over intermediate

\begin{tabular}{|c|c|c|c|c|c|c|}
\hline $\begin{array}{l}\text { No. } \\
\text { crt. }\end{array}$ & Config. & $\begin{array}{l}Q_{r c l} \\
{[\mathbf{W}]}\end{array}$ & $\begin{array}{l}Q_{r c 2} \\
{[\mathbf{W}]}\end{array}$ & $\underset{[\mathbf{W}]}{\boldsymbol{Q}_{r}}$ & $\begin{array}{l}Q_{\text {inc }} \\
{[\mathbf{W}]}\end{array}$ & $\begin{array}{c}\varepsilon \\
{[\%]}\end{array}$ \\
\hline \multirow{3}{*}{1} & $(1 / 4) \mathrm{D}$ & 31.90 & 198.29 & 230.19 & 291.38 & 79 \\
\hline & $\mathrm{v}=0 .(2 / 4) \mathrm{D}$ & 74.34 & 61.91 & 136.25 & 227.08 & 60 \\
\hline & $2 \mathrm{~m} / \mathrm{s} \quad(3 / 4) \mathrm{D}$ & 129.15 & 10.48 & 139.64 & 240.76 & 58 \\
\hline \multirow{3}{*}{2} & \begin{tabular}{|l|l|}
$(1 / 4) \mathrm{D}$ \\
\end{tabular} & 23.15 & 327.29 & 350.44 & 411.67 & 85 \\
\hline & $\mathrm{v}=0 .(2 / 4) \mathrm{D}$ & 141.13 & 89.73 & 230.86 & 321.76 & 72 \\
\hline & $5 \mathrm{~m} / \mathrm{s} \quad(3 / 4) \mathrm{D}$ & 215.54 & 21.55 & 237.09 & 338.22 & 70 \\
\hline
\end{tabular}
surfaces had been calculated according to glazing refraction indexes $\tau_{i}$.

Table 3. Dynamic insulation efficiency.

Dynamic insulation efficiency varies between 58\% and $85 \%$. The optimal solution corresponds to the placement of sun protection at $(1 / 4 \mathrm{D}), 7.5 \mathrm{~cm}$ from the exterior glazing and air flow rate corresponding to air inlet velocity of $0.5 \mathrm{~m} / \mathrm{s}$.

Variation of thermal-energy indexes characteristic for dynamic insulation efficiency $\varepsilon$, relative to placement of sun protection and air flow are shown in the following image (Fig. 9).

Analysing this image, dynamic insulation efficiency in summer decreases when protection is shifted towards the interior of the channel and is significantly influenced by the air flow.

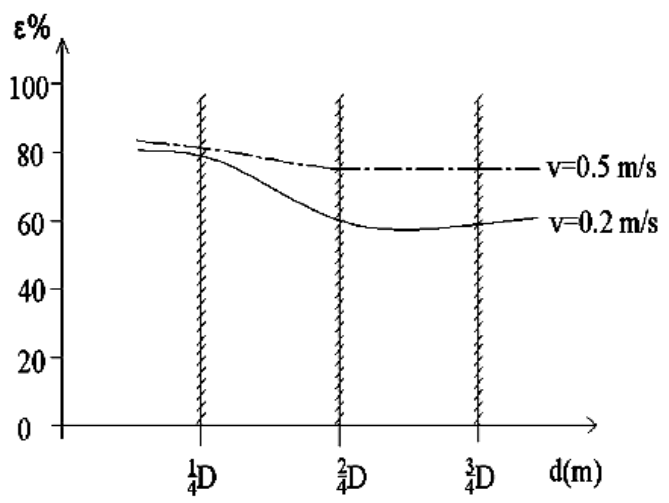

Fig. 9. Variation of dynamic insulation efficiency. 
Convective transfer index varies between 0.242 and $1.156 \mathrm{~W} / \mathrm{m}^{2} \mathrm{~K}$ for exterior channel and inlet speed of $0.2 \mathrm{~m} / \mathrm{s}$, and when inlet speed increases to $0.5 \mathrm{~m} / \mathrm{s}$ indexes values double for protection placements at $2 / 4 \mathrm{D}$ and $3 / 4 \mathrm{D}$. Highest value of the convective exchange coefficient for the inner channel is recorded when protection is located in the middle of the channel, reaching the value of $3.28\left(\mathrm{~W} / \mathrm{m}^{2} \mathrm{~K}\right)$, while for other positions, the convective heat exchange coefficient has a close value, ranging between $3.05\left(\mathrm{~W} / \mathrm{m}^{2} \mathrm{~K}\right)$ and $3.12\left(\mathrm{~W} / \mathrm{m}^{2} \mathrm{~K}\right)$.

\section{Conclusions}

This study analysed the influence of sun protection position inside the channel of a double-glazed façade in relation to dynamic insulation efficiency under summer conditions.

Analysing the numerical results, one can emphasize that effective sun protection, blind types, is directly proportional to the air flow speed inside the channel and inversely proportional to the distance against the outer glazing.

Ultimately, the best position of sunscreen with regards to dynamic insulation efficiency is towards exterior glazing, corresponding to an air velocity in inlet section of $0.5 \mathrm{~m} / \mathrm{s}$.

\section{References}

1. Poirazis H, Double Skin Façades for Office Buildings - Literature Review. Lund University Sweeden; 2004

2. AmirHosein G, Umberto B, Ali G, Nastaran M, Intelligent Façades in Low-Energy Buildings. British Journal of Environment \& Climate Change 2012:437464

3. Xu L, Ojima T, Field experiments on natural energy utilization in a residential house with a double skin façade system. Building and Environment 2007;42(5):2014-2023

4. Ye P, Harrison SJ, Oosthuizen PH, Naylor D, Convective Heat Transfer from a Window with Venetian Blind: Detailed Modeling. Refrigerating and AirConditioning Engineers (ASHRAE) Transactions 1999;105(2):1031-1037

5. Collins M, Harrison SJ, Oosthuizen PH, Naylor D, Sensitivity Analysis of Heat Transfer from an Irradiated Window and Horizontal Louvered Blind Assembly. ASHRAE Trans 2002;108(1):503-511

6. Manz H, Schaelin A, Simmler H, Airflow patterns and thermal behaviour of mechanically ventilated glass double façades. Building and Environment 2004; 39:1023-1033.

7. Safer N, Modeling of double-skin façades types equipped with sunscreens: multiscale approaches. [PhD thesis]. Centre de Thermique de Lyon (CETHIL): Institut National des Sciences Appliquées de Lyon; 2006.
8. Kuznik F, Catalina T, Gauzere L, Woloszyn M, Roux JJ, Numerical modeling of combined heat transfers in a double skin façade-Full-scale laboratory experiment validation. Thermal engineering 2011;31(14-15):30433054

9. Andjelković AS, Cvjetković TB, Djaković DD, Stojanović IH, Development of simple calculation model for energy performance of double skin façades. Thermal Science 2012;16:251-267

10. Pasut W, De Carli M, Evaluation of various CFD modelling strategies in predicting airflow and temperature in a naturally ventilated double skin façade. Thermal Engineering 2012;37:267-274

11. Guohui G, Simulation of buoyancy-induced flow in open cavities for natural ventilation. Energy and Buildings 2006;38:410-420

12. Popa C, Ospir D, Fohanno S, Chereches C, Numerical simulation of dynamical aspects of natural convection flow in a double-skin façade. Energy and Buildings 2012;50:229-233

13. Ignjatović MG, Blagojević BD, Stojanović BV, Stojiljković MM, Influence of glazing types and ventilation principles in double skin façades on delivered heating and cooling energy during heating season in an office building. Thermal Science 2012;16:461-469

14. Perez-Grande I, Meseguer J, Alonso G, Influence of glass properties on the performance of double-glazed façades. Applied Thermal Engineering 2005;25(1718):3163-3175

15. Thalfeldt M, Pikas E, Kurnitski J, Voll H, Façade design principles for nearly zero energy buildings in a cold climate. Energy and Buildings 2013;67:309-321

16. Chan ALS, Chow TT, Calculation of overall thermal transfer value (OTTV) for commercial buildings constructed with naturally ventilated double skin façade in subtropical Hong Kong. Energy and Buildings 2014;69:14-21

17. Jinqing $\mathrm{P}$, Lin L, Hongxing $\mathrm{Y}$, An experimental study of the thermal performance of a novel photovoltaic double-skin façade in Hong Kong. Solar Energy 2013;97:293-304

18. Nizovtsev MI, Belyi VT, Sterlygov AN, The façade system with ventilated channels, for thermal insulation of newly constructed and renovated buildings. Energy and Buildings 2014;75:60-69

19. Cherecheş M, Cherecheş NC, Hudişteanu S, Specific energy indicators for ventilated façades and glazed. Rev. Constructii 2012;2:24-30

20. Pleşca A, Thermal analysis of a traction system with double conducting points in steady state conditions. Electric Power Systems Research 2013;97:126-132

21. Wakil NE, Chereches NC, Padet J, Numerical study of heat transfer and fluid flow in a power transformer. International Journal of Thermal Sciences 2006;45:615626

22. CG Popovici, VV Cirlan, TD Mateescu, NC Chereches, SV Hudisteanu, Influence of various angles 
of the venetian blind on the efficiency of a double skin façade, Energy Procedia 85, 2016, 416-424

23. C Chereches, M Chereches, L Miron, S Hudisteanu, New criterion proposal for transition from natural to forced convection (prescribed wall flux), Energy Procedia 85, 2016, 109-117 